\title{
Children \& the Law I: Editorial
}

\author{
Niños y la ley I: Editorial \\ Carlos Eduardo Peixoto ${ }^{\mathrm{a}, \mathrm{b}}$ \& Michael E. Lamb ${ }^{\mathrm{c}}$ \\ ${ }^{a}$ Portuguese National Institute of Legal Medicine and Forensic Sciences, I.P., Portugal \\ ${ }^{b}$ Centre for Studies in Human Development of the Portuguese Catholic University, Porto, Portugal \\ ${ }^{c}$ University of Cambridge, Cambridge, United Kingdom
}

The 20th century changed the way western societies viewed children and their wellbeing, shifting from an outdated representation of children as miniature adults (Sá, 1992), to a modern view of a transitional period preceding adulthood (Sá, 2011). This focus prompted not only the recognition of children's immaturity and the need for physical protection, but also consequently a call for legal protection (Foucault, 1975). Nevertheless, for the last few decades, legal and criminal justice systems have struggled to adapt procedures and jurisprudence so as to reflect our growing understanding of child development, the consequences of violence against children, and the factors that promote or prevent juvenile delinquency. Psychology, specifically developmental psychology, has contributed decisively to our burgeoning understanding, by identifying the biological, cognitive, social, and contextual factors that influence child development and outcomes in adulthood (for reviews, see Bornstein \& Lamb, 2015). Anticipating these issues, Hugo Munsterberg (1908) proposed a solution to the problems regarding children in legal contexts at the beginning of the 20th century. Psychological research has since documented the limitations and challenges that normative development imposes on judicial proceedings and decision making, particularly in the domain of children's interactions with the judicial system (for a review see Lamb, Malloy, Hershkowitz, \& La Rooy, 2015), including the impact, for example, on topics as diverse as testimonial capacity and the resolution of custody disputes. There is also extensive evidence that some early experiences, including victimisation, can have traumatic consequences for children (e.g., Cicchetti \& Valentino, 2008), and that specific developmental pathways seem to characterise those who later engage in delinquent and criminal behaviour (Moffitt, 2006). On the whole, psychological research has been a crucial source of knowledge to the judicial system, helping to shape and promote more child-friendly practices.

In this thematic section of Revista de Psicología, our objective is to show, in an Iberoamerican context, how scientific contributions by psychological researchers can help us better understand and, consequently intervene more appropriately in legal contexts, especially when children's interests and well-being are involved. This issue includes papers that not only illustrate the efforts to understand local problems, but also contribute to the international research literature by addressing such problems. In this first part of the thematic section, papers focus primarily on three topics: children's testimony, the impact of violence against children and ways to minimise those experiences and consequences, as well as juvenile violence and delinquency.

Cómo citar: Peixoto, C. E. \& Lamb, M. E. (2015). Children \& the Law I: Editorial. Revista de Psicología, 24(1), 1-4. http://dx.doi.org/10.5354/0719-0581.2015.37921 
Crimes against children are rarely associated with physical and medical evidence or eyewitness testimony, making children's statements the only available source of information. Focus on the enhancement of children's testimony, especially by using evidence-based interview protocols, and by video recording those interviews to use as evidence-in-chief in court, has been an important concern in several countries. For example, Chile's parliament is, at the time of writing, debating about the implementation of such a system (Navarro, Mettifogo, Antivilo, Veliz, \& García, 2015). The National Institute of Child Health and Human Development Interview Protocol, NICHD (Lamb, Hershkowitz, Orbach, \& Esplin, 2008) represents an important milestone on the road towards higher quality and reliability in children's testimony, and it is now used in several countries around the world (La Rooy et al., 2015). The NICHD Protocol, informed by decades of research on child development and interview techniques, is a flexible and usable tool that minimizes suggestive interactions between interviewers and interviewees, and maximizes the amount of information obtained from the latter. In this issue, we include two papers (by Aznar-Blefari \& Padilha, 2015; and Hackbarth, Williams, \& Lopes, 2015) describing the efforts to adapt and implement the NICHD Protocol in Brazil. Both papers, using samples from different states, demonstrate how the use of the Protocol was associated with improvements in the quality of children's testimony. Another paper (by Melo \& Sani, 2015) describes how Portuguese public prosecutors evaluate children's statements, and explains the key role they play in judicial decision making, underlining the importance of developing better strategies to obtain children's testimony; given that this affects credibility assessment and charging decisions that have potentially life-transforming implications for suspects.

Sexual abuse is a crime against children, and its characteristics and dynamics have been of considerable interest to psychological researchers. Today our understanding of sexual abuse is well grounded in an extensive empirical database and in comprehensive theoretical approaches, with growing scholarship concerning the impact on children's development, the dynamics of abuse, the characteristics of sexual abusers, and the intervention strategies that seem to work (for a review, see Lamb et al., 2015). In this issue, we include a paper (Baía, Veloso, Habigzang, Dell'Aglio, \& Magalhães, 2015) that addresses a key issue in our growing understanding of the dynamics of disclosure. Using samples of sexual abuse victims in two Brazilian states, the authors show the impact that child characteristics and the victim's location have on disclosure. Despite our growing knowledge and several changes in legal systems around the world regarding how these issues are addressed, child abuse victims still encounter several barriers in the judicial context. Often, the judicial system becomes another venue for victimisation, as described in the paper written by Lama and colleagues (2015), who argue that being involved in the legal system often impedes psychological adaptation to the abusive experience.

Sexual abuse is not the only type of crime against children addressed in this issue of Revista de Psicología. In one paper, Mels and Fernández (2015) discuss indirect victimisation, particularly community violence, in Uruguay. Nearly $85 \%$ of the children surveyed had been exposed to at least a type of violence and the authors urge other researchers to focus more attention on this type of violence against children, as it also may affect their psychological well-being and mental health. 
Juvenile delinquency is the focus of the last paper in this issue, specifically, of the case of foreign juvenile. Fernández-Suárez, Pérez Sánchez, Fernández-Alonso, Herrero Olaizola, \& Rodríguez-Díaz (2015) describe the socio-demographic, psychological, and criminal characteristics of foreign juveniles, who have committed crimes in Asturias, Spain. At a time where migration and immigration policies have become highly controversial, particularly in the European context, the issue of how we should deal with foreign-born children's problems, and the ways in which the legal system should address them, is of critical importance.

Finally, we would like to thank Revista de Psicología Editorial Board and staff for inviting us to edit this thematic section of the journal, and for their assistance in bringing this issue to completion. We would also like to acknowledge and express our gratitude to all the colleagues who agreed to review one or more of the many papers that were submitted. All of the papers published here contribute to our growing understanding of children and the law and promote the embrace of practices that serve the ideals of justice for all children.

\section{References}

Aznar-Blefari, C. \& Padilha, M. G. S. (2015). Capacitação para o uso do Protocolo NICHD em profissionais sul-brasileiros. Revista de Psicología, 24(1), 1-19. http://dx.doi.org/10.5354/0719-0581.2015.37198

Baía, P. A. D., Veloso, M. M. X., Habigzang, L. F., Dell'Aglio, D. D., \& Magalhães, C. M. C. (2015). Padrões de revelação e descoberta do abuso sexual de crianças e adolescentes. Revista de Psicología, 24(1), 1-19. http://dx.doi.org/10.5354/0719-0581.2015.37007

Bornstein, M. H. \& Lamb, M. E. (2015). Developmental science: An advanced textbook ( $7^{\text {th }}$ edition). New York, NY: Psychology Press.

Cicchetti, D. \& Valentino, K. (2008). An ecological-transactional perspective on child maltreatment: Failure of the average expectable environment and its influence on child development. In D. Cicchetti \& D. Cohen (Eds.), Developmental psychopathology $\left(2^{\text {nd }}\right.$ ed., Vol. 3, pp. 129-201) [Risk, disorder and adaptation]. New Jersey: John Wiley \& Sons.

Fernández-Suárez, A., Pérez Sánchez, B., Fernández-Alonso, L., Herrero Olaizola, J., \& Rodríguez-Díaz, F. (2015). Perfil de los menores infractores extranjeros acompañados y no acompañados en Asturias. Revista de Psicología, 24(1), 1-18. http://dx.doi.org/10.5354/0719-0581.2015.36911

Foucault, M. (1975). Surveiller et Punir. Gallimard: Paris.

Hackbarth, C., Williams, L. C. A., \& Lopes, N. R. L. (2015). Avaliação de capacitação para utilização do Protocolo NICHD em duas cidades brasileiras. Revista de Psicología, 24(1), 1-18. http://dx.doi.org/10.5354/0719-0581.2015.36916

Lama, X., Gutiérrez, C., Capella, C., Dussert, D., Rodríguez, L., Beiza, G., \& Águila, D. (2015). Superación de agresiones sexuales infanto-juveniles y el sistema judicial: una visión desde los participantes. Revista de Psicología, 24(1), 1-19. http://dx.doi.org/10.5354/0719-0581.2015.36914 
Lamb, M. E., Hershkowitz, I., Orbach, Y., \& Esplin, P. W. (2008). Tell me what happened. Wiley: Chichester.

Lamb, M. E., Malloy, L. C., Hershkowitz, I., \& La Rooy, D. J. (2015). Children and the law. In M. E. Lamb (Ed.), Handbook of child psychology and developmental science $\left(7^{\text {th }}\right.$ ed., Vol. 3, pp. 1-146). Hoboken, NJ: Wiley.

La Rooy, D. J., Brubacher, S. P., Aromäki-Stratos, A., Cyr, M., Hershkowitz, I., Korkman, J., ... Lamb, M. E. (2015). The NICHD Protocol: A review of an internationally-used evidence-based tool for training child forensic interviewers. Journal of Criminological Research, Policy \& Practice, 1(2), 76-89.

http://doi.org/10.1108/JCRPP-01-2015-0001

Melo, M. F. \& Sani, A. I. (2015). A audição da criança na tomada de decisão dos magistrados. Revista de Psicología, 24(1), 1-19.

http://dx.doi.org/10.5354/0719-0581.2015.37067

Mels, C. \& Fernández, L. (2015). Violencia comunitaria en adolescentes desfavorecidos: exposición, impacto percibido y consecuencias psicológicas. Revista de Psicología, 24(1), 1-21.

http://dx.doi.org/10.5354/0719-0581.2015.36863

Moffitt, T. E. (2006). Life-course persistent versus adolescence-limited antisocial behavior: Research review. In D. Cicchetti \& D. Cohen (Eds.), Developmental psychopathology ( $2^{\text {nd }}$ ed., Vol. 3, pp. 570-598) [Risk, disorder, and adaptation]. New Jersey: John Wiley \& Sons.

Münsterberg, H. (1908). On the witness stand: Essays on psychology and crime. New York: Doubleday, Page \& Co.

Navarro, C., Mettifogo, D., Antivilo, A., Veliz, S., \& García, F. (June, 2015). Adaptation process of an evidence based model of investigative interviewing: The Chilean case. Paper presented at the VII Conference of the International Investigative Interviewing Research Group (iIIRG), Melbourne, Australia.

Sá, I. G. (1992). Abandono de crianças, infanticídio e aborto na sociedade portuguesa tradicional através das fontes jurídicas. Penélope - Fazer E a Desfazer a História, 8, 75-89.

Sá, I. G. (2011). A criança e as idades da vida. In N. G. Monteiro (Ed.), História da vida privada em Portugal: A idade moderna (pp. 72-95). Lisboa: Temas e Debates. 